\title{
1 Role of microzooplankton during a Phaeocystis sp. bloom in the
}

\section{Oosterschelde (SW Netherlands)}

3

4

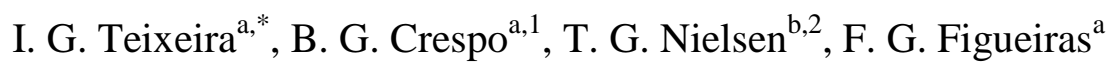

5

6

${ }^{a}$ Instituto de Investigacións Mariñas (CSIC), Eduardo Cabello 6, 36208 Vigo, Spain

7

$8{ }^{\mathrm{b}}$ Department of Marine Ecology, The National Environmental Research Institute, University

9 of Aarhus, Frederiksborgvej 399, PO Box 358, 4000 Roskilde, Denmark.

10

$11{ }^{1}$ Present address: Departament de Biologia Marina I Oceanografia, Institut de Ciències del

12 Mar (CSIC), Pg Marítim de la Barceloneta 37-49, 08003 Barcelona, Spain

13

$14{ }^{2}$ Present addres: National Institute of Aquatic Resources, DTU Aqua Section for

Oceanecology and Climate, Technical University of Denmark, Kavalergården 6, 2920

16 Charlottenlund, Denmark

17

18

19

*Corresponding author:

20 Email: isabeltx@iim.csic.es

21 Telephone: +34986231930

22 Fax: +34 986292767

23

24 RUNNING HEAD: Role of microzooplankton during a Phaeocystis sp. bloom 


\section{$1 \quad$ ABSTRACT}

2 The impact of microzooplankton on the plankton community was assessed during a bloom of

3 Phaeocystis sp. in the Oosterschelde basin (SW Netherlands). Chlorophyll a concentration

4 and Phaeocystis sp. abundance reached maxima values in the middle of the sampling period

$5 \quad\left(\sim 27 \mathrm{mg}\right.$ chl $a \mathrm{~m}^{-3}$ and $3.4 \times 10^{10}$ cells $\mathrm{m}^{-3}$, respectively). The bloom collapse coincided with

6 the last sampling day, when accentuated decreases in chlorophyll $a$ concentrations $(\sim 11 \mathrm{mg}$

$\left.7 \quad \mathrm{chl} a \mathrm{~m}^{-3}\right)$ and Phaeocystis sp. cells numbers $\left(\sim 1.3 \times 10^{10}\right.$ cells $\left.\mathrm{m}^{-3}\right)$ were recorded.

8 Microzooplankton organisms were significant consumers of both phytoplankton and

9 heterotrophic plankton. Although Phaeocystis sp. was the most consumed organism (336 \pm 71

$\mathrm{mg} \mathrm{C} \mathrm{m}{ }^{-3} \mathrm{~d}^{-1}$ ), microzooplankton impact on its standing stock was lower than on the stocks of

11 other less abundant organisms. This impact was also lower during the peak of the bloom,

12 when colonial forms of Phaeocystis sp. presumably predominated, than during the bloom

13 collapse, when free-living cells were supposedly more abundant. The impact of

14 microzooplankton on heterotrophic organisms was higher than on phytoplankton, and

increased when the bloom collapsed. Picoheterotrophs experienced the highest impact on their standing stock $\left(\sim 75 \% \mathrm{~d}^{-1}\right)$ and production $\left(\sim 90 \% \mathrm{~d}^{-1}\right)$. These results demonstrate that during a Phaeocystis sp. bloom, the microbial food web was responsible for channelling a significant fraction of plankton biomass, either from direct consumption of Phaeocystis sp. cells or through consumption of heterotrophs, which would have been favoured by the high quantities of organic matter released during the bloom collapse.

KEY WORDS: Phaeocystis sp., microzooplankton, microbial food web, Oosterschelde, SW

Netherlands 


\section{Introduction}

Phaeocystis (Prymnesiophyceae, Haptophyta) is a worldwide distributed phytoplankton genus with a significant role in biogeochemical processes, primarily due to the production of high amounts of organic carbon and the production of sulphur compounds involved in climate regulation (e.g. Schoemann et al., 2005). The major particularity of this organism is related to its polymorphic life cycle, in which the solitary stage characterised by flagellate or non-motile free-living small cells $(3-9 \mu \mathrm{m})$ can alternate with the colonial stage composed of non-motile cells embedded in a mucilaginous matrix (e.g. Rousseau et al., 1994, 2007). When in the form of these mucilaginous colonies, which can reach several millimetres in diameter, Phaeocystis spp. frequently forms nearly mono-specific blooms of huge biomass in polar and temperate regions during the spring (e.g. Schoemann et al., 2005). The magnitude of these blooms is such that locally they can account for up to $70 \%$ of the annual primary production (Joiris et al., 1982).

Despite numerous investigations, several details on the life cycle of Phaeocystis spp. are still not totally understood. This must be due to its morphological and physiological variability and the contrasting environmental conditions of the different systems where this alga can temporally dominate. High nutrient concentrations and high irradiance have been assigned as responsible for promoting the transformation of solitary cells into colonial forms (Veldhuis et al., 1986; Verity et al., 1988a; Peperzak, 1993). Conversely, the bloom demise, habitually occurring within a short time period, has been attributed to nutrient limitation and/or changes in temperature, both causing the colony disruption and the release of the colonial cells into the water column (Veldhuis et al., 1986; Verity et al., 1988b). Pelagic consumption, cell lysis and sedimentation are other processes that can be responsible for the sudden disappearance of biomass from the water column (Wassmann, 1994; Weisse et al., 1994; Brussaard et al., 1996). Though sedimentation has been observed to occur on several 
1 occasions, cell lysis mediated by viral infection and pelagic consumption are frequently

2 identified as the main responsible factors for the termination of Phaeocystis spp. blooms

3 (Rousseau et al., 2000; Brussaard et al., 2005a; Baudoux et al., 2006).

The magnitude of the pelagic consumption of Phaeocystis spp. cells and derived material, which determines the fraction of biomass that is transferred through the food web, has major implications for the fluxes of matter and energy in the systems where this organism dominates. Colonial forms, which are protected by a tough skin (Hamm et al., 1999) that aids them to avoid viral infection and grazing on individual cells, apparently are suitable for consumption by copepods and larger animals. Thus, colonial forms could contribute to sustain the classical short food chain. In fact, it has been recently reported that colony formation and enlargement in Phaeocystis spp. is enhanced by the presence of micrograzers, which could indicate that this strategy corresponds to a mechanical defence against predation by microzooplankton (Jakobsen and Tang, 2002; Tang, 2003). However, the trophic significance of colonial biomass for metazoans is uncertain, and divergent reports regarding ingestion rates, the nutritive value of preys and adverse effects on consumers are widespread through literature (Weisse et al., 1994). These contrasting results seem to be related to the variability in the size ratio between predators and colonies, the physiological state of preys and whether experiments were performed in laboratory with Phaeocystis spp. as single preys or in situ (Nejstgaard et al., 2007). In general, crustacean grazers depict a much lower grazing impact in the field than in the laboratory, which could be due to the presence of alternative preys in situ, 21 and changes in the chemical properties of Phaeocystis spp. in the laboratory conditions which 22 could favour their consumption. Rather than consuming Phaeocystis spp. biomass during bloom periods, copepods have been observed to feed on alternative preys, namely microzooplankton (Hansen et al., 1993; Gasparini et al., 2000). In contrast, microzooplankton apparently shows preference for solitary cells of only a few micrometers (Admiraal and 
1 Venekamp, 1986; Weisse and Scheffel-Möser, 1990; Tang et al., 2001; Brussaard et al.,

2 2005a), although large naked dinoflagellates, such as Noctiluca scintillans and Gyrodinium

3 spirale, have been observed to feed on colonies (Jakobsen and Tang, 2002; Stelfox-

4 Widdicombe et al., 2004). In addition, both colony matrix disintegration and cell lysis at the

5 end of the bloom period, which increase the quantities of dissolved organic matter in the

6 water column (Alderkamp et al., 2007), should enter the microbial food web through

7 enhanced bacterial production and microzooplankton bacterivory (Fernández et al., 1992; van

8 Boeckel et al., 1992; Brussaard et al., 1995; Brussaard et al., 1996; Rousseau et al., 2000).

As the fate of the high biomass produced during Phaeocystis spp. blooms has a major implication for biogeochemical cycles in marine systems, further assessment of the role of

11 microzooplankton during these blooms is fundamental to reach a better understanding of the

12 functioning of the marine systems dominated by these organisms. In this context, an intensive and multidisciplinary research was conducted in the Oosterschelde (SW Netherlands) (Fig. 1) between 4 and 13 May 2004, coinciding with the development and decay of a Phaeocystis sp. bloom when phytoplankton biomass, primary production and the microzooplankton feeding impact were studied.

\section{Materials and methods}

\subsection{Experimental procedure}

Sampling took place on board of R/V Luctor between 4 and 13 May 2004. Seawater samples to determine chlorophyll $a(\operatorname{chl} a)$ concentration, phytoplankton biomass and primary production were taken at three depths (surface, middle and bottom) during high tide in a location close to a mussel bed (Fig. 1) using Niskin bottles. The sampling depths (1-6 m) depended on the tidal range, which varied according to the sampling days. On 9 and 12 May 
1 column were measured with a CTD to which a spherical PAR quantum sensor was attached.

2 Practical salinity was converted to absolute salinity $\left(\mathrm{g} \mathrm{kg}^{-1}\right)$ according to TEOS-10 Primer,

3 where $\delta \mathrm{S}_{\mathrm{A}}=0$ in this shallow water system.

\subsection{Analyses}

6 For chl $a$, three replicates of $50 \mathrm{ml}$ were filtered onto GF/F filters. Pigments were extracted overnight in $5 \mathrm{ml} \mathrm{96 \%} \mathrm{ethanol} \mathrm{in} \mathrm{the} \mathrm{dark} \mathrm{and} \mathrm{chl} a$ concentration was determined against a chl $a$ standard after reading fluorescence before and after acidification on a Turner Designs Model 700 Fluorometer.

Samples for microplankton counts were preserved in Lugol's iodine solution and sedimented in composite sedimentation chambers. Diatoms, dinoflagellates, other flagellates $>20 \mu \mathrm{m}$ and ciliates were identified and counted at species level, when possible, using an inverted microscope. Differentiation of phototrophic species of dinoflagellates, other flagellates (hereafter, flagellates) and ciliates was basically done following Lessard and Swift (1986) and Larsen and Sournia (1991); however, epifluorescence microscopy (see below) was also used to assign phototrophy within these plankton groups. The biovolumes of each taxon were calculated from the dimensions and shapes according to Hillebrand et al. (1999). The plasmatic volumes of diatoms and total cell volume of dinoflagellates, flagellates $>20 \mu \mathrm{m}$ and ciliates were converted to cell carbon following Strathmann (1967) for diatoms and dinoflagellates, Verity et al. (1992) for flagellates and Putt and Stoecker (1989) for ciliates.

21 Fixation procedure did not allowed us to quantify the number of colonies of Phaeocystis sp., and consequently the carbon biomass calculated for this species does not include the carbon content of the colonial matrix (Rousseau et al., 1990; van Rijssel et al., 1997).

Primary production was measured as carbon assimilation after $24 \mathrm{~h}$ in situ incubations. 
1 inoculated with ca. $3.7 \times 10^{5} \mathrm{~Bq}$ of $\mathrm{NaH}^{14} \mathrm{CO}_{3}$. Then, samples were placed in a rope with

2 specially constructed holders. A weight kept the line vertical, whereas the surface of the line 3 was maintained afloat by a large buoy. After $24 \mathrm{~h}$ of incubation samples were recovered and

4 filtered through $25 \mathrm{~mm} \mathrm{GF/F}$ filters under low vacuum pressure $(<20 \mathrm{kPa})$. Filters were

5 placed in scintillation vials and left in $\mathrm{HCl}$ fumes atmosphere for $12 \mathrm{~h}$ to remove unassimilated

$6{ }^{14} \mathrm{C}$. Radioisotope incorporation was determined with a liquid scintillation counter using the 7 external standard and the channel ratio methods to correct for quenching.

\subsection{Microzooplankton feeding impact}

The feeding impact of microzooplankton on the several organisms of the plankton community was determined using the dilution technique (Landry and Hassett, 1982) on 4, 6, 8, 10 and 13 May 2004. Water was collected from the surface with a Niskin bottle as soon as possible in the morning. All experimental containers, bottles and tubing were soaked in $10 \% \mathrm{HCl}$ and rinsed with Milli Q water before each experiment. Filtered seawater was obtained by gravity filtration through $0.8 / 0.2 \mu \mathrm{m}$ Suporcap filter into a 251 container. Sample water was transferred to another 251 container, very gently through a tube. In the laboratory, dilutions were prepared directly in 21 polycarbonate bottles (Nalgene). A total of 6 dilutions, in the proportions of $100,80,60,40,20$ and $10 \%$ of sample relatively to filtered seawater were performed, with two replicates each. These bottles were incubated for $24 \mathrm{~h}$ in running seawater and at in-situ temperature and surface light conditions. During incubation period, 21 these bottles were regularly gently hand-rotated to avoid massive sedimentation.

Samples to determine the biomasses of plankton organisms $\leq 200 \mu \mathrm{m}$ were taken from the natural seawater at the beginning of the incubation and from each incubation bottle at the end of the incubation. Samples for microplankton biomass determinations were processed as described above. Metazooplankton $<200 \mu \mathrm{m}$ and mesozooplankton were found occasionally 
1 and at very low concentrations in the dilution bottles. So, their importance as grazers in these

2 experiments was not considered. Pico- and nanoplankton were determined in subsamples of

$310 \mathrm{ml}$ fixed with buffered $0.2 \mu \mathrm{m}$ filtered formaldehyde ( $2 \%$ final concentration) and stained

4 with DAPI at $0.1 \mu \mathrm{g} \mathrm{ml}^{-1}$ final concentration (Porter and Feig, 1980). After 10 minutes in the

5 dark, samples were filtered through $0.2 \mu \mathrm{m}$ black Millipore-Isopore filters. The filters were

6 then immersed in low fluorescence immersion oil and examined at x1000 magnification using

7 an epifluorescence microscope. Autotrophic organisms were enumerated under blue light

8 excitation and heterotrophic organisms were counted under excitation with UV light.

9 Bacterial biomass was estimated according to Lee and Furhmann (1987). Dimensions of

10 several individuals of the other groups were taken and cell volumes were calculated assuming

11 spherical shape. Cell carbon was estimated following Verity et al. (1992) for pico- and

12 nanoflagellates and Bratbak and Dundas (1984) for Synechococcus-type cyanobacteria.

13 Changes in total plankton $(\leq 200 \mu \mathrm{m})$ biomass and in the several plankton groups

14 occurring between the beginning $\left(\mathrm{C}_{0}\right)$ and the end $\left(\mathrm{C}_{\mathrm{t}}\right)$ of the incubation time $(\mathrm{t}=1$ day) were 15 used to calculate the net growth rates $\left(\mathrm{k}, \mathrm{d}^{-1}\right)$ :

$$
k=\frac{1}{t} \cdot \ln \left(\frac{C_{t}}{C_{0}}\right)
$$

Mortality rates due to microzooplankton $\left(\mathrm{m}, \mathrm{d}^{-1}\right)$ were calculated as the slope and the specific growth rates $\left(\mu, \mathrm{d}^{-1}\right)$ as the $y$-axis intercept of the linear regression between the net growth rates and the fraction of unfiltered seawater (X) (Landry and Hassett, 1982):

$$
k=\mu-m \cdot X
$$

In the cases of non-linear responses (saturated and saturated-increased, see Teixeira and Figueiras, 2009), the specific growth rate $(\mu)$ was obtained by the $y$-axis intercept of the regression of the linear part of the response. The mortality rate $(\mathrm{m})$ was then obtained by 
1 equation 2, replacing the specific growth rate calculated and using the net growth rate

2 obtained in the undiluted sample (Gallegos, 1989; Teixeira and Figueiras, 2009).

3 The daily mortality impact on the standing stock $\left(\% \mathrm{SS}, \% \mathrm{~d}^{-1}\right)$ and on production $\left(\% \mathrm{P}, \% \mathrm{~d}^{-}\right.$

$4{ }^{1}$ ) were calculated as:

5

6

11 where $C_{m}\left(\mathrm{mg} \mathrm{m}^{-3}\right)$ is: estimated as:

$$
\begin{gathered}
\% S S=\left(1-e^{-m}\right) \times 100 \\
\% P=\frac{m}{\mu} \times 100
\end{gathered}
$$

The quantity of carbon consumed $\left(G, \mathrm{mg} \mathrm{m}^{-3} \mathrm{~d}^{-1}\right)$ and produced $\left(P, \mathrm{mg} \mathrm{m}^{-3} \mathrm{~d}^{-1}\right)$ were

$$
G=m \times C_{m}
$$

$$
P=\mu \times C_{m}
$$

$$
C_{m}=C_{0}\left[e^{(\mu-m) t}-1\right] /(\mu-m) t
$$

\section{Results}

\subsection{Hydrographic conditions}

The water column (maximum depth $=6.5 \mathrm{~m}$ ) was well mixed from surface to bottom during all days (Figs. $2 \mathrm{a} \& \mathrm{~b}$ ). There was a slight increase in the salinity of the water column, which varied between $30.8 \mathrm{~g} \mathrm{~kg}^{-1}$ on the first 3 days and values higher than $31 \mathrm{~g} \mathrm{~kg}^{-1}$ on the following days (Fig. 2a). Temperature did not show any tendency, varying between 12.6 and $13.3{ }^{\circ} \mathrm{C}$ (Fig. 2b).

The light attenuation coefficient in the water column (Fig. 2c) varied between 0.66 and

$231.03 \mathrm{~m}^{-1}$, with the highest value occurring on 8 May and the lowest on 13 May, at the end of 
1 the sampling. Relatively low values $\left(0.71 \mathrm{~m}^{-1}\right)$ were also recorded at the beginning of the

2 sampling, on 4 May (Fig. 2c).

\subsection{Chl a and Phaeocystis sp.}

Chl $a$ concentration increased from $20.4( \pm 1.0)$ to $26.8( \pm 1.3) \mathrm{mg}$ chl $a \mathrm{~m}^{-3}$ during the first 5 days, falling to $11.1( \pm 0.2) \mathrm{mg} \operatorname{chl} a \mathrm{~m}^{-3}$ on the last day (Fig. 3a). Differences in chl $a$ concentrations between the 3 sampling depths were not significant $(0.40<\mathrm{p}<0.88$; t-test for paired samples).

Chl $a$ concentration was positively correlated with phytoplankton abundance $(\mathrm{r}=0.91, \mathrm{p}<$ $0.01)$ and carbon biomass $(\mathrm{r}=0.89, \mathrm{p}<0.01)$, two variables that showed a similar evolution during the sampling period (Figs. $3 b$ \& c). The phytoplankton community was dominated by Phaeocystis sp., which accounted for $\sim 98 \%$ of the total phytoplankton abundance and $\sim 90 \%$ of the total phytoplankton biomass (Figs. $3 \mathrm{~b} \& \mathrm{c}$ ). This species reached an abundance of $3.4 \mathrm{x}$ $10^{10}\left( \pm 1.3 \times 10^{10}\right)$ cells $\mathrm{m}^{-3}$ and a biomass of $871( \pm 343) \mathrm{mg} \mathrm{C} \mathrm{m}^{-3}$ during the peak of the bloom on 8 May, and then dropped to $1.3 \times 10^{10}\left( \pm 2.5 \times 10^{9}\right)$ cells $\mathrm{m}^{-3}$ and $345( \pm 63) \mathrm{mg} \mathrm{C}$ $\mathrm{m}^{-3}$ on the last day. Differences between depths in abundance and biomass of Phaeocystis sp. and total phytoplankton were not significant $(0.40<\mathrm{p}<0.95$; t-test for paired samples $)$.

Despite Phaeocystis sp. was mainly forming colonies (as it was observed in fresh samples and deduced from the high accumulation of gelatinous structures on filters), the lugol's iodine that was added to preserve the phytoplankton samples destroyed these structures. This resulted in a much higher abundance of Phaeocystis sp. as solitary cells (99.4\%) than as colonial forms $(0.6 \%)$ in the counted samples.

As a result of the correlation between phytoplankton carbon biomass and chl $a$ concentration, the autotrophic carbon to $\operatorname{chl} a(\mathrm{AC}: \mathrm{chl} a)$ ratio (Fig. 3d) remained relatively 
1 constant around a mean value of $34 \pm 3$ during the sampling period. Nevertheless, the AC:chl

$2 a$ ratio was slightly but significantly lower ( $\mathrm{p}<0.05$, t-test for two samples) when chl $a$ and

3 phytoplankton biomass were increasing ( $31 \pm 2,4$ to 7 May) than when these two variables

4 were decreasing ( $37 \pm 2,8$ to 13 May).

5

\subsection{Primary production}

Primary production decreased with depth (Fig. 4) in accordance with the light attenuation coefficient in the water column (Fig. 2c). Thus, primary production varied between 102 and $608 \mathrm{mg} \mathrm{C} \mathrm{m}^{-3} \mathrm{~d}^{-1}$ at the surface, 76 and $444 \mathrm{mg} \mathrm{C} \mathrm{m}^{-3} \mathrm{~d}^{-1}$ at the middle depth and between 0 and $89 \mathrm{mg} \mathrm{C} \mathrm{m}^{-3} \mathrm{~d}^{-1}$ at the bottom layer (Fig. 4). Highest differences between depths were observed on 8 May. The zero value recorded at the bottom layer that day coincided with the strongest light attenuation in the water column (Fig. 2c), which led to a photic layer shallower than the depth at the station. Depth integrated primary production varied between 353 and $1626 \mathrm{mg} \mathrm{C} \mathrm{m}^{-2} \mathrm{~d}^{-1}$, with lowest values at the beginning and the end of the sampling period (Fig. 4) and highest values in between, on 8 and 10 May. Integrated primary production was positively correlated with integrated phytoplankton carbon biomass $(r=0.74 ; \mathrm{p}<0.05)$.

\subsection{Microzooplankton feeding impact}

In addition to Phaeocystis sp., which represented $\sim 90 \%$ of total phytoplankton biomass (Fig. 5a), diatoms were also present in the initial plankton populations of dilution experiments. Nevertheless, diatoms accounted for a minor fraction (3-7\%) of the total autotrophic carbon (AC). The biomass of diatoms increased from $\sim 25 \mathrm{mg} \mathrm{C} \mathrm{m}^{-3}$ during the first days to $\sim 40 \mathrm{mg} \mathrm{C} \mathrm{m}^{-3}$ on the last days. Among this group, Rhizosolenia imbricata, Guinardia delicatula, Cerataulina pelagica and small and large Pseudo-nitzschia spp. were the most abundant species. The phototrophic ciliate Mesodinium rubrum, autotrophic 
1 dinoflagellates and picoautotrophs (Synechococcus-like cyanobacteria and picoflagellates)

2 were also found, but their contribution to phytoplankton biomass was very low (Fig. 5a). The evolution of heterotrophs was different from that of autotrophs (Fig. 5b), showing a peak on 6

4 May $\left(155 \mathrm{mg} \mathrm{C} \mathrm{m}^{-3}\right)$ due to the high biomass of heterotrophic nanoflagellates (HNF) on that

5 day $\left(121 \mathrm{mg} \mathrm{C} \mathrm{m}^{-3}\right)$. HNF, which dominated within microzooplankton community at the

6 beginning of the sampling period, accounting almost for $90 \%$ of the microzooplankton

7 biomass, decreased from 6 May onwards. On the last day of sampling, HNF with a biomass of $12 \mathrm{mg} \mathrm{C} \mathrm{m}{ }^{-3}$ only represented $20 \%$ of microzooplankton carbon. Heterotrophic picoflagellates (HPF) showed also a decreasing tendency during the sampling period, but their biomass was much smaller, varying between 3.8 and $1.3 \mathrm{mg} \mathrm{C} \mathrm{m}^{-3}$. On the contrary, the importance of heterotrophic dinoflagellates (mainly naked forms $>20 \mu \mathrm{m}$ ), ciliates (mainly aloricate choreotrichs $>50 \mu \mathrm{m}$ ) and heterotrophic bacteria (HB) increased through the sampling period (Fig. 5b); heterotrophic dinoflagellates from 3 to $26 \mathrm{mg} \mathrm{C} \mathrm{m}^{-3}$, ciliates from 7 to $23 \mathrm{mg} \mathrm{C} \mathrm{m}^{-3}$ and $\mathrm{HB}$ from 19 to $37 \mathrm{mg} \mathrm{C} \mathrm{m}{ }^{-3}$.

According to the outcome of the dilution experiments (Table 1), heterotrophic pico- and nanoplankton (HB, HPF and HNF), Synechococcus and Phaeocystis sp. were consumed during all the sampling period. Diatoms were also consumed, but only on May 13. Growth and mortality rates were highly variable amongst the several organisms, with growth rates varying between 0.15 and $3.08 \mathrm{~d}^{-1}$ and mortality rates between 0 and $2.64 \mathrm{~d}^{-1}$. The rates were generally higher for total heterotrophic carbon (HC) $\left(1.03 \leq \mu \leq 1.48 \mathrm{~d}^{-1}\right.$ and $0.69 \leq \mathrm{m} \leq 1.48$ $\left.\mathrm{d}^{-1}\right)$ than for total AC $\left(0.16 \leq \mu \leq 0.91 \mathrm{~d}^{-1}\right.$ and $\left.0.23 \leq \mathrm{m} \leq 0.58 \mathrm{~d}^{-1}\right)$. Growth and grazing rates of AC were very similar to those obtained for Phaeocystis sp. $\left(0.15 \leq \mu \leq 0.96 \mathrm{~d}^{-1}\right.$ and $0.26 \leq$ $\left.\mathrm{m} \leq 0.62 \mathrm{~d}^{-1}\right)$

On average, $40 \pm 5 \% \mathrm{~d}^{-1}$ of the whole plankton standing stock $\leq 200 \mu \mathrm{m}$ was consumed by microzooplankton (Fig. 6a). HC was more impacted (Fig. 6a, $67 \pm 11 \% \mathrm{~d}^{-1}$ ) than AC (Fig. 6a, 
$\left.134 \pm 9 \% \mathrm{~d}^{-1}\right)$. Moreover, there was an increase in the consumption of the standing stock of HC

2 from $50 \% \mathrm{~d}^{-1}$ being ingested at the beginning of the sampling to almost $80 \% \mathrm{~d}^{-1}$ at the end

3 (Fig. 6a). Among autotrophs, the lowest grazing impact $\left(21 \% \mathrm{~d}^{-1}\right)$ was found on 8 May (Fig.

4 6a), coinciding with the maximum peak in the abundance of Phaeocystis sp. (Fig. 3b \& c).

5 The impact on the standing stock of Phaeocystis sp. $\left(37 \pm 9 \% \mathrm{~d}^{-1}\right)$ was relatively low, always

6 below $50 \% \mathrm{~d}^{-1}$ (Fig. 6b). Regarding the several plankton groups, the highest impact occurred

7 on the standing stock of picoheterotrophs $\left(75 \pm 6 \% \mathrm{~d}^{-1}\right.$ for $\mathrm{HB}$ and $74 \pm 19 \% \mathrm{~d}^{-1}$ for HPF),

8 followed by HNF $\left(62 \pm 36 \% \mathrm{~d}^{-1}\right)$, though HNF were not consumed on 4 May (Fig. 6c).

9 Concerning the microzooplankton impact on production, a sudden increase was observed

10 for $\mathrm{AC}$ and $\mathrm{TC}$ on the last day of sampling (Fig. 6d), when consumption shifted from $63 \pm$

$1118 \% \mathrm{~d}^{-1}$ of $\mathrm{AC}$ and $74 \pm 23 \% \mathrm{~d}^{-1}$ of TC produced during the previous days to $373 \% \mathrm{~d}^{-1}$ of the

$12 \mathrm{AC}$ and $265 \% \mathrm{~d}^{-1}$ of the TC produced on 13 May. This evolution closely resembled that observed for the impact on the production of Phaeocystis sp. (Fig. 6e), which derived from a consumption of $67 \pm 20 \% \mathrm{~d}^{-1}$ of the production between 4 and 10 May to a value of $422 \% \mathrm{~d}^{-1}$ on 13 May. The impact on the production of the other two phytoplankton groups with significant responses in the dilution experiments was highly variable, ranging from 17 to $100 \% \mathrm{~d}^{-1}$ for Synechococcus and from 52 to $98 \% \mathrm{~d}^{-1}$ for autotrophic picoflagellates (APF) (Fig. 6e). In contrast, the microzooplankton impact on the production of $\mathrm{HC}$ gradually increased over the sampling period, varying from $56 \% \mathrm{~d}^{-1}$ on the first day to $113 \% \mathrm{~d}^{-1}$ on the last day (Fig. 6d), showing a relatively constant and significant impact $\left(96 \pm 16 \% \mathrm{~d}^{-1}\right)$ on the 21 production of HB (Fig. 6f). The other two heterotrophic groups, HPF and HNF, also experienced a high impact $\left(87 \pm 33 \% \mathrm{~d}^{-1}\right.$ and $73 \pm 45 \% \mathrm{~d}^{-1}$, respectively) on their production, although it was highly variable (Fig. 6f).

In spite of these percentages, consumption of autotrophic biomass (255-420 $\mathrm{mg} \mathrm{C} \mathrm{m}^{-3} \mathrm{~d}^{-}$

\footnotetext{
${ }^{1}$ ) was always higher than consumption of heterotrophic biomass (90-161 $\mathrm{mg} \mathrm{C} \mathrm{m}^{-3} \mathrm{~d}^{-1}$ ) (Fig.
} 
1 7a). Phaeocystis sp. was virtually the only phytoplankton species consumed from 4 to 10 May

2 and represented $95 \%$ of the total AC removed on 13 May, when diatoms were also consumed

3 (Fig. 7b). Among heterotrophs (Fig. 7c), HNF, which were not consumed on the first day of

4 sampling, were highly consumed on 6 May $\left(131 \mathrm{mg} \mathrm{C} \mathrm{m}^{-3} \mathrm{~d}^{-1}\right)$, showing after that a

5 decreasing tendency. In contrast, the HB biomass daily removed by microzooplankton

6 increased over the sampling period, from $28 \mathrm{mg} \mathrm{C} \mathrm{m}^{-3} \mathrm{~d}^{-1}$ on the first day to $45 \mathrm{mg} \mathrm{C} \mathrm{m}^{-3} \mathrm{~d}^{-1}$

7 in the last dilution experiment. The autotrophic biomass produced (68-980 $\left.\mathrm{mg} \mathrm{C} \mathrm{m}^{-3} \mathrm{~d}^{-1}\right)$

8 during the sampling period showed higher variations than the biomass consumed (Figs. 7a \&

9 d). Phaeocystis sp. was the phytoplankton species with the highest production (Figs. 7e),

10 representing $>96 \%$ of the total autotrophic carbon produced. In contrast, consumption (90-161

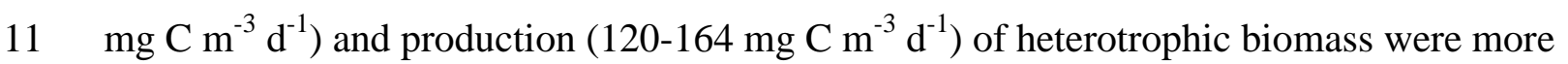

12 tightly coupled (Figs. 7a,d,c,f), with HNF showing higher production during the first 3 days

13 of sampling and $\mathrm{HB}$ acquiring more importance at the end.

14 Growth and microzooplankton grazing rates derived from dilution experiments (Table 1)

15 were used to predict the expected Phaeocystis sp. biomass in the water column on the

16 following day (Fig. 8). The observed and predicted biomasses were in reasonable agreement

17 at the beginning of the bloom, with predicted biomass exceeding the observed biomass on 6

18 and $49 \mathrm{mg} \mathrm{C} \mathrm{m}^{-3}$ on May 5 and 7, respectively. However, this difference was much higher

19 when the bloom started to decay (May 11), with observed biomass being $403 \mathrm{mg} \mathrm{C} \mathrm{m}^{-3}$ lower

20 than expected biomass estimated considering only growth and microzooplankton grazing rates

21 obtained in dilution experiments.

\section{Discussion}

4.1. The Phaeocystis sp. bloom 
Blooms of Phaeocystis spp. in the Oosterschelde (Laanbroek et al., 1985; Bakker et al.,

2 1990) and in the adjacent North Sea (e.g. Veldhuis et al., 1986; Weisse \& Scheffel-Möser,

3 1990; Rousseau et al., 2000) are frequent in spring. Here, we followed an almost

4 monospecific Phaeocystis sp. bloom in the Oosterschelde well reflected in the evolution of

5 chl $a$ concentration and cell abundance (Figs. $3 \mathrm{a} \& \mathrm{~b}$ ). The bloom was also discernible in the

6 evolution of primary production (Fig. 4), which was correlated with Phaeocystis sp. biomass

7 (Fig. 3c), and in the evolution of the light attenuation coefficient (Fig. 2c). Even though the progress of this bloom was observed inside the Oosterschelde, its advection from the North

Sea cannot be disregarded, because the increase in salinity recorded during the sampling period (Fig. 2a) points to the possible input of water from the North Sea, saltier than the water 11 in the Oosterschelde (Laanbroek et al., 1985).

The high chl $a$ concentration $\left(20 \mathrm{mg} \operatorname{chl} a \mathrm{~m}^{-3}\right)$ and the high cell abundance $\left(\sim 23 \times 10^{9}\right.$ cells $\mathrm{m}^{-3}$ ) of Phaeocystis sp. (Figs. 3a \& b) recorded on the first day of sampling were above the threshold reported for the formation of colonies (Schoemann et al., 2005). This indicates that our sampling started after the onset of the bloom, when Phaeocystis sp. was already in the colonial form. The bloom rapidly evolved to reach its maximum 4 days later, and then declined. Changes in temperature and/or nutrient limitation have been assigned as triggering factors for the beginning of bloom collapse (Veldhuis et al., 1986; Verity et al., 1988b). In this case temperature did not show any significant change (Fig. 2b), but nutrient limitation could have been responsible for finishing this event. Although not having a nutrient record during the sampling period, we do have nutrient data before (on April 29) and after (May 17) the survey. Thus, on April 29 nitrate concentration was $25.44 \mu \mathrm{mol} \mathrm{l}^{-1}$ while on May 17 was $8.53 \mu \mathrm{mol} \mathrm{l}^{-1}$ (T. Ysebaert, personal communication), indicating a high nutrient decrease during that period. By its turn, phosphate concentrations were very low on both days $(0.1$ and 
1 North Sea (Veldhuis et al., 1986; Peperzak et al., 1998). Nonetheless, the decrease in nitrate

2 concentrations could lead to a reduction in Phaeocystis biomass that can be viewed as the

3 bloom collapse Also the changes observed in the AC:chl $a$ ratios (Fig. 3d), with slightly but

4 significant higher ratios during the demise phase, could point to nutrient limitation as the

5 possible factor triggering the bloom decline. However, this could also be a consequence of a

6 decrease in the light attenuation coefficient in the water column with the progress of the

7 bloom (Fig. 2c). Other loss factors, as sedimentation, have also been reported (Wassmann,

8 1994), but sinking seems unusual in this region where tidal currents are strong enough to

9 prevent it. In fact, in this work we did not observe accumulation of phytoplankton in bottom

10 layers at the end of sampling (Fig. 4).

\subsection{Microzooplankton feeding impact}

Our results showed that microzooplankton organisms were significant consumers in the pelagic system, but their impact varied during the bloom period (Fig. 6). The highest quantity of carbon biomass consumed by microzooplankton corresponded to Phaeocystis sp. cells (Figs. 7a \& b). However, this pattern was forced by the dominance of this species during the sampling period resulting in higher quantities consumed even though mortality rates were lower than those of the other plankton groups (Table 1). Despite these high quantities consumed, microzooplankton was unable to control the bloom development, consuming only a fraction of the Phaeocystis sp. standing stock and production (Figs. $6 \mathrm{~b} \&$ e). However, on

21 the last sampling day, when the bloom decayed, microzooplankton consumption exceeded 4 times the production of this haptophyte (Fig. 6e). These variations in consumption must be related to the structural changes occurring in Phaeocystis sp. through the sampling period.

24 With exception of few dinoflagellate species, such as Noctiluca scintillans (Jakobsen and Tang, 2002) or Gyrodinium spirale (Stelfox-Widdicombe et al., 2004), microzooplankton is 
1 not an efficient consumer either of the whole colonial structure or the colonial single cells

2 protected by the colony skin (Hamm et al., 1999). However, when Phaeocystis sp. is in the

3 form of single cells in the water column, microzooplankton organisms are able to ingest them

4 (Admiraal and Venekamp, 1986; Weisse and Scheffel-Möser, 1990; Tang et al., 2001). Here

5 we found a higher microzooplankton grazing on Phaeocystis sp. on the last day (Figs. 6b \&

6 e), when colonies presumably had collapsed and cells were free-living. As on the previous

7 days Phaeocystis sp. was probably forming colonies, the impact of microzooplankton would

8 have occurred on the less abundant solitary cells that usually are present in the water column

9 coexisting with colonial structures (Rousseau et al. 1994). Consumption of some colonial

10 forms could also have occurred, because large naked forms predominated among

11 heterotrophic dinoflagellates and these organisms could feed on Phaeocystis sp. colonies as

12 Gyrodinium spirale do it (Stelfox-Widdicombe et al., 2004). It must be noted however that

13 the accentuated impact on Phaeocystis sp. production on May 13 was not due to a higher

14 grazing mortality, but to the low growth rate of Phaeocystis sp. on this day, several times

15 lower than the mortality rate (Table 1). This low growth rate can indicate nutrient limitation,

16 as stated before, but also that microzooplankton was not the only mortality factor for

17 Phaeocystis sp. on this day. When viral lysis is significant, the conventional dilution protocol can under-estimate the specific growth rates (Evans et al., 2003; Baudoux et al., 2006). Cell lysis mediated by viral attack has been shown to be very important in the termination of the

Phaeocystis spp. blooms (Rousseau et al., 2000; Brussaard et al., 2005a; Baudoux et al.,

21 2006). Thus, the high microzooplankton grazing on Phaeocystis sp. production at the end of

22 the bloom must be taken carefully, as probably both viral lysis and grazing by micro-

23 heterotrophs were acting on this alga simultaneously. This can also explain the results shown

24 in Fig. 8, where other loss factors than microzooplankton grazing were apparently responsible

25 for the disappearance of Phaeocystis sp. biomass from the water column on May 11, when the 
1 bloom started to decay. Besides viral lysis and grazing by micro-heterotrophs, other loss

2 processes can also include pelagic consumption by mesozooplankton (Weisse et al., 1994) or

3 even benthic consumption by mussels (Smaal and Twisk, 1997), which are abundant in this

4 system. Colony destruction occurring when the bloom started to collapse probably made

$5 \quad$ Phaeocystis sp. more susceptible to all consumers.

6 Consumption by microzooplankton during the Phaeocystis sp. bloom was not restricted to 7 this alga. Picoautotrophs (APF and Synechococcus) were also grazed (Table 1), although the quantities of carbon consumed of these organisms were insignificant due to their low biomasses (Fig. 7b). Grazing on diatoms, which only occurred on the last day (Table 1), could be related to the presence of Pseudo-nitzschia spp. Pennate diatoms, including these species, are known to be attached to Phaeocystis sp. colonies (Peperzak et al., 1998; Sazhin et al., 2007). Thus, Pseudo-nitzschia spp. could have been attached to the colonial forms during the bloom and hence be protected against grazing. On the last day, with the disintegration of colonies, Pseudo-nitzschia spp. could became free-living, and as Phaeocystis sp. free cells, be more susceptible to pelagic consumption.

In addition to phytoplankton, heterotrophs were also an important nutritional source for microzooplankton (Figs. 7a \& c). In relative terms of biomass and abundance, microzooplankton impact on heterotrophs was actually higher than on phytoplankton (Figs. 6a). Among this group, picoheterotrophs (HPF and HB) were highly impacted by microzooplankton, with $\sim 75 \%$ of their standing stock and $\sim 90 \%$ of their production being 21 channelled to the microbial food web (Figs. $6 \mathrm{c} \& \mathrm{f}$ ). The microzooplankton consumption was not enough to fully control HB, which showed slight increases in biomass (Fig. 5b) and production (Fig. 7f) over the sampling period, reaching maximum values during the bloom decay. This increase can be associated with the response of HB to the increase in dissolved organic matter concentrations due to colony disintegration (Laanbroek et al., 1985; Veldhuis 
1 et al., 1986; Verity et al., 1988b; Noordkamp et al., 2000; Rousseau et al., 2000; Brussaard et

2 al., 2005b). HNF were also consumed (Fig. 7c), in agreement with other studies indicating

3 consumption of these organisms by microzooplankton during Phaeocystis sp. blooms

4 (Brussaard et al., 1995, 1996; Rousseau et al., 2000).

5 Noteworthy, microzooplankton impact increased towards the end of the sampling period

6 (Fig. 6). This was not only observed for grazing on phytoplankton, but also for predation on

7 heterotrophic components. This increasing importance of the microbial food web in the transfer of biomass with the progress of the bloom adds new evidences to previous reports

9 (Admiraal and Venekamp, 1986; Weisse and Scheffel-Möser, 1990; Brussaard et al., 1995; Peperzak et al., 1998; Rousseau et al., 2000) supporting the view that Phaeocystis sp. blooms 11 stimulate the dominance of the microbial food web.

\subsection{Concluding remarks}

14 These results indicate that a significant fraction of the Phaeocystis sp. bloom was channelled through the microbial food web, with two pathways in which microzooplankton is a direct intervenient. Firstly, direct consumption of Phaeocystis sp. cells by microzooplankton occurred in all experiments and increased during the bloom decay. Secondly, microzooplankton consumption of small heterotrophs allowed the return to the food web of the high amounts of organic matter released during the collapse of the bloom (Alderkamp et al., 2007): HB taking advantage of the released organic matter, and HNF being favoured by the increase in bacterial production. Thus, microzooplankton, which is consumed by copepods during Phaeocystis blooms (Hansen et al., 1993; Gasparini et al., 2000), transfers the photosynthesised organic matter to higher trophic levels, linking the microbial and classical food webs and therefore enhancing the efficiency of the pelagic food web. 


\section{Ackowledgements}

2 We thank our MABENE colleagues and to the crew from R/V Luctor for their help during the

3 field campaign. This work was funded by the EU project MABENE (grant: EKV3-2001-

4 00144). Special thanks to Dr. T. Ysebaert for providing nutrient data and Fig.1 and Dr. P.J.

5 Herman, Dr. Paffenhofer and 2 anonymous reviewers for the comments on an earlier version

6 of the manuscript. I. G. T. was supported by a FCT (Portuguese Foundation for Science and

7 Technology) doctoral fellowship (SFRH/BD/11309/2002) and B.G.C. by a CSIC-ESF I3P

8 fellowship.

9 


\section{References}

Admiraal, W. and Venekamp, L.A.H., 1986. Significance of tintinnid grazing during blooms of Phaeocystis pouchetii (Haptophyceae) in Dutch coastal waters. Neth. J. Sea Res. 20(1), 61-66.

Alderkamp, A.-C., Buma, A.G.J. and Van Rijssel, M., 2007. The carbohydrates of Phaeocystis and their degradation in the microbial food web. Biogeochemistry 83, 99118.

Bakker, C., Herman, P.M.J. and Vink, M., 1990. Changes in seasonal succession of phytoplankton induced by the storm-surge barrier in the Oosterschelde (S.W.Netherlands). J. Plankton Res. 12(5), 947-972.

Baudoux, A.-C., Noordeloos, A.A.M., Veldhuis, M.J.W. and Brussaard, C.P.D., 2006. Virally induced mortality of Phaeocystis globosa during two spring blooms in temperate coastal waters. Aquat. Microb. Ecol. 44, 207-217.

Bratbak, G. and Dundas, I., 1984. Bacterial dry matter content and biomass estimation. Appl. Environ. Microb. 48(4), 755-757.

Brussaard, C.P.D., Gast, G.J., van Duyl, F.C. and Riegman, R., 1996. Impact of phytoplankton bloom magnitude on a pelagic microbial food web. Mar. Ecol. Prog. Ser. 144, 211-221.

Brussaard, C.P.D., Kuipers, B. and Veldhuis, M.J.W., 2005a. A mesocosm study of Phaeocystis globosa population dynamics I. Regulatory role of viruses in bloom control. Harmful Algae 4, 859-874.

Brussaard, C.P.D., Mari, X., Van Bleijswijk, J.D.L. and Veldhuis, M.J.W., 2005b. A mesocosm study of Phaeocystis globosa (Prymnesiophyceae) population dynamics II. Significance for the microbial community. Harmful Algae 4, 875-893. 
1 Brussaard, C.P.D., Riegman, R., Noordeloos, A.A.M., Cadée, G.C., Witte, H., Kop, A.J., Nieuwland, G., van Duyl, F.C. and Bak, R.P.M., 1995. Effects of grazing, sedimentation and phytoplankton cell lysis on the structure of a coastal pelagic food web. Mar. Ecol. Prog. Ser. 123, 259-271.

Evans, C., Archer, S.D., Jacquet, S. and Wilson, W.H., 2003. Direct estimates of the contribution of viral lysis and microzooplankton grazing to the decline of a Micromonas spp. population. Aquat. Microb. Ecol. 30, 207-219.

Fernández, E., Serret, P., Madariaga, I.d., Harbour, D.S. and Davies, A.G., 1992. Photosynthetic carbon metabolism and biochemical composition of spring phytoplankton assemblages enclosed in microcosms: the diatom - Phaeocystis sp. succession. Mar. Ecol. Prog. Ser. 90, 89-102.

Gallegos, C.L., 1989. Microzooplankton grazing on phytoplankton in Rhode River, Maryland: nonlinear feeding kinetics. Mar. Ecol. Prog. Ser. 57(1), 23-33.

Gasparini, S., Daro, M.H., Antajan, E., Tackx, M., Rousseau, V., Parent, J.-Y. and Lancelot, C., 2000. Mesozooplankton grazing during the Phaeocystis globosa bloom in the southern bight of the North Sea. J. Sea Res. 43, 345-356.

Hamm, C.E., Simson, D.A., Merkel, R. and Smetacek, V., 1999. Colonies of Phaeocystis globosa are protected by a thin but tough skin. Mar. Ecol. Prog. Ser. 187, 101-111.

Hansen, F.C., Reckermann, M., Klein Breteler, W.C.M. and Riegman, R., 1993. Phaeocystis blooming enhanced by copepod predation on protozoa: evidence from incubation experiments. Mar. Ecol. Prog. Ser. 102, 51-57.

Hillebrand, H., Dürselen, C., Kirschtel, D., Pollingher, U. and Zohary, T., 1999. Biovolume calculation for pelagic and benthic microalgae. J. Phycol. 35, 403-424. 
1 Jakobsen, H.H. and Tang, K.W., 2002. Effects of protozoan grazing on colony formation in Phaeocystis globosa (Prymnesiophyceae) and the potential costs and benefits. Aquat. Microb. Ecol. 27, 261-273.

Joiris, C., Billen, G., Lancelot, C., Daro, M.H., Mommaerts, J.P., Bertels, A., Bossicart, M., Nijs, J. and Hecq, J.H., 1982. A budget of carbon cycling in the Belgian coastal zone: relative roles of zooplankton, bacterioplankton and benthos in the utilization of primary production. Neth. J. Sea Res. 16, 260-275.

Laanbroek, H.J., Verplanke, J.C., Visscher, P.R.M.d. and Vuyst, R.d., 1985. Distribution of phyto- and bacterioplankton growth and biomass parameters, dissolved inorganic nutrients and free amino acids during a spring bloom in the Oosterschelde basin, The Netherlands. Mar. Ecol. Prog. Ser. 25, 1-11.

Landry, M.R. and Hassett, R.P., 1982. Estimating the grazing impact of marine microzooplankton. Mar. Biol. 67, 283-288.

Lee, S. and Fuhrman, J.A., 1987. Relationships between biovolume and biomass of naturally derived marine bacterioplankton. Appl. Environ. Microb. 53, 1298-1303.

Lessard, E.J. and Swift, E., 1986. Dinoflagellates from the North Atlantic classified as phototrophic or heterotrophic by epifluorescence microscopy. J. Plankton Res. 8(6), 1209-1215.

Nejstgaard, J.C., Tang, K.W., Steinke, M., Dutz, J., Koski, M., Antajan, E. and Long, J.D., 2007. Zooplankton grazing on Phaeocystis: a quantitative review and future chalenges. Biogeochemistry 83, 147-172.

Noordekamp, D.J.B., Gieskes, W.W.C., Gottschal, J.C., Forney, L.J. and van Rijssel, M., 2000. Acrylate in Phaeocystis colonies does not affect the surrounding bacteria. J. Sea Res. 43, 287-296. 
1 Peperzak, L., 1993. Daily irradiance governs growth rate and colony formation of Phaeocystis (Prymnesiophyceae). J. Plankton Res. 15(7), 809-821.

Peperzak, L., Colijn, F., Gieskes, W.W.C. and Peeters, J.C.H., 1998. Development of the diatom-Phaeocystis spring bloom in the Dutch coastal zone of the North Sea: the silicon depletion versus the daily irradiance threshold hypothesis. J. Plankton Res. 20(3), 517-537.

Porter, K.G. and Feig, Y.S., 1980. The use of DAPI for identifying and counting aquatic microflora. Limnol. Oceanogr. 25(5), 943-948.

Putt, M. and Stoecker, D.K., 1989. An experimental determined carbon:volume ratio for marine "oligotrichous" ciliates from estuarine and coastal waters. Limnol. Oceanogr. 34(6), 1097-1103.

Rousseau, V., Becquevort, S., Parent, J.-Y., Gasparini, S., Daro, M.-H., Tackx, M. and Lancelot, C., 2000. Trophic efficiency of the planktonic food web in a coastal ecosytem dominated by Phaeocystis colonies. J. Sea Res. 43, 357-372.

Rousseau, V., Chrétiennot-Dinet, M.-J., Jacobsen, A., Verity, P. and Whipple, S., 2007. The life cycle of Phaeocystis: state of knowledge and presumptive role in ecology. Biogeochemistry 83, 29-47.

Rousseau, V., Mathot, S. and Lancelot, C., 1990. Calculating carbon biomass of Phaeocystis sp. from microscopic observations. Mar. Biol. 107, 305-314.

Rousseau, V., Vaulot, D., Casotti, R., Cariou, V., Lenz, J., Gunkel, J. and Baumann, M., 1994. The life cycle of Phaeocystis (Prymnesiophyceae): evidence and hypothesis. J. Marine Syst. 5, 23-39.

Sazhin, A.F., Artigas, L.F., Nejstgaard, J.C. and Frischer, M.E., 2007. The colonization of two Phaeocystis species (Prymnesiophyceae) by pennate diatoms and other protists: a significant contribution to colony biomass. Biogeochemistry 83, 137-145. 
1 Schoemann, V., Becquevort, S., Stefels, J., Rousseau, V. and Lancelot, C., 2005. Phaeocystis blooms in the global ocean and their controlling mechanisms: a review. J. Sea Res. 53, 43-66.

Smaal, A.C. and Twisk, F., 1997. Filtration and absorption of Phaeocystis cf. globosa by the mussel Mytilus edulis L. J. Exp. Mar. Biol. Ecol. 209, 33-46.

Stelfox-Widdicombe, C.E., Archer, S.D., Burkill, P.H. and Stefels, J., 2004. Microzooplankton grazing in Phaeocystis and diatoms-dominated waters in the southern North Sea in spring. J. Sea Res. 51, 37-51.

Strathmann, R., 1967. Estimating the organic carbon content of phytoplankton from cell volume or plasma volume. Limnol. Oceanogr. 12(3), 411-418.

Tang, K.W., 2003. Grazing and colony size development in Phaeocystis globosa (Prymnesiophyceae): the role of a chemical signal. J. Plankton Res. 25(7), 831-842.

Tang, K.W., Jakobsen, H.H. and Visser, A.W., 2001. Phaeocystis globosa (Prymnesiophyceae) and the planktonic food web: Feeding, growth, and the trophic interactions among grazers. Limnol. Oceanogr. 46(8), 1860-1870.

Teixeira, I.G. and Figueiras, F.G., 2009. Feeding behaviour and non-linear responses in dilution experiments in a coastal upwelling system. Aquat. Microb. Ecol. 55, 53-63.

van Boekel, W.H.M., Hansen, F.C., Riegman, R. and Bak, R.P.M., 1992. Lysis-induced decline of a Phaeocystis spring bloom and coupling with the microbial foodweb. Mar. Ecol. Prog. Ser. 81, 269-276.

van Rijssel, M., Hamm, C.E. and Gieskes, W.W.C., 1997. Phaeocystis globosa (Prymnesiophyceae) colonies: hollow structures built with small amounts of polysaccharides. Eur. J. Phycol. 32, 185-192.

Veldhuis, M.J.W., Colijn, F. and Venekamp, L.A.H., 1986. The spring bloom of Phaeocystis pouchetii (Haptophyceae) in Dutch coastal waters. Neth. J. Sea Res. 20(1), 37-48. 
1 Verity, P., Robertson, C.Y., Tronzo, C.R., Andrews, M.G., Nelson, J.R. and Sieracki, M.E.,

\section{6} 1992. Relationships between cell volume and the carbon and nitrogen content of marine photosynthetic nanoplankton. Limnol. Oceanogr. 37(7), 1434-1446.

Verity, P.G., Villareal, T.A. and Smayda, T.J., 1988a. Ecological investigations of blooms of colonial Phaeocystis pouchetii - I. Abundance, biochemical composition, and metabolic rates. J. Plankton Res. 10(2), 219-248.

Verity, P.G., Villareal, T.A. and Smayda, T.J., 1988b. Ecological investigations of blooms of colonial Phaeocystis pouchetii. II. The role of life-cycle phenomena in bloom termination. J. Plankton Res. 10(4), 749-766.

Wassmann, P., 1994. Significance of sedimentation for the termination of Phaeocystis blooms. J. Marine Syst. 5, 81-100.

Weisse, T. and Scheffel-Möser, U., 1990. Growth and grazing loss rates in single-celled Phaeocystis sp. (Prymnesiophyceae). Mar. Biol. 106, 153-158.

Weisse, T., Tande, K., Verity, P., Hansen, F. and Gieskes, W., 1994. The trophic significance of Phaeocystis blooms. J. Marine Syst. 5, 67-79.

8




\section{$1 \quad$ Figure legends}

2

3 Fig. 1. Map of the Oosterschelde with the location of the sampling site (black dot) and its 4 position in the Dutch coast (inset).

6 Fig. 2. Vertical profiles of (a) absolute salinity $\left(\mathrm{g} \mathrm{kg}^{-1}\right)$, (b) temperature $\left({ }^{\circ} \mathrm{C}\right)$, and (c) light 7 attenuation coefficient $\left(\mathrm{m}^{-1}\right)$ in the water column.

9 Fig. 3. Mean values in the water column of (a) chl $a$ concentration (mg chl $a \mathrm{~m}^{-3}$ ), (b) cell abundance of Phaeocystis sp. and total phytoplankton (cells $\mathrm{m}^{-3}$ ), (c) carbon biomass of Phaeocystis sp. and total phytoplankton $\left(\mathrm{mg} \mathrm{C} \mathrm{m}^{-3}\right)$ and (d) autotrophic carbon to chl $a$ ratio. Vertical bars in a, b, and c are standard deviations.

Fig. 4. Primary production rates at the surface, middle and bottom depths $\left(\mathrm{mg} \mathrm{C} \mathrm{m}^{-3} \mathrm{~d}^{-1}\right)$. Values of integrated primary production $\left(\mathrm{mg} \mathrm{C} \mathrm{m}^{-2} \mathrm{~d}^{-1}\right)$ are also given.

Fig. 5. Initial carbon biomass $\left(\mathrm{mg} \mathrm{C} \mathrm{m}^{-3}\right)$ for each dilution experiment of (a) autotrophic and (b) heterotrophic plankton community. APF: autotrophic picoflagellates, AC: autotrophic carbon, HPF: heterotrophic picoflagellates, HB: heterotrophic bacteria, HNF: heterotrophic nanoflagellates, HC: heterotrophic carbon. Left y-axis corresponds to bars and right y-axis corresponds to lines.

Fig. 6. Percentages of the standing stock (a-c) and production (d-f) daily consumed by microzooplankton of the bulk plankton groups (a \& d), autotrophic plankton groups (b \& e) and heterotrophic plankton groups (c \& f). AC, autotrophic carbon; HC, heterotrophic carbon; 
1 TC, total carbon; APF, autotrophic picoflagellates, HPF, heterotrophic picoflagellates; HNF,

2 heterotrophic nanoflagellates; HB, heterotrophic bacteria.

3

$4 \quad$ Fig. 7. Plankton carbon biomass $\left(\mathrm{mg} \mathrm{C} \mathrm{m}^{-3}\right)$ daily ingested by microzooplankton (left panels)

5 and daily produced (right panels). (a \& d) total autotrophic and heterotrophic plankton, (b \&

6 e), autotrophic plankton groups, (c \& f) heterotrophic plankton groups. AC, autotrophic

7 carbon; HC, heterotrophic carbon; APF, autotrophic picoflagellates, HPF, heterotrophic

8 picoflagellates; HNF, heterotrophic nanoflagellates; HB, heterotrophic bacteria. Right y-axis

9 in b \& e corresponds to lines.

10

11 Fig. 8. Comparison between Phaeocystis sp. biomass $\left(\mathrm{mg} \mathrm{C} \mathrm{m}^{-3}\right)$ observed in situ and

12 estimated using the growth and microzooplankton grazing rates obtained from the dilution experiments started the previous day.

14 
Table 1. Mortality $\left(m, \mathrm{~d}^{-1}\right)$ and growth $\left(\mu, \mathrm{d}^{-1}\right)$ rates obtained from the dilution experiments. AC: total autotrophic carbon, APF: autotrophic picoflagellates, HC: total heterotrophic carbon, HPF: heterotrophic picoflagellates, HNF: heterotrophic nanoflagellates, HB: heterotrophic bacteria, TC: total plankton carbon biomass $(\leq 200 \mu \mathrm{m}) . \mathrm{r}^{2}$ : coefficient of determination for the linear regressions $(\mathrm{p}<0.05)$ between the net growth rate and the fraction of unfiltered seawater. In cases of saturated or saturated-increased responses, $\mathrm{r}^{2}$ was obtained for the linear part of the response (Teixeira and Figueiras, 2009). When $\mathrm{r}^{2}$ is not given, the growth rate was obtained with only the two highest diluted bottles (Gallegos, 1989). a: non-linear responses. ns: not significant.

\begin{tabular}{|c|c|c|c|c|c|c|c|c|c|c|c|c|c|c|c|}
\hline & \multicolumn{3}{|c|}{04 May } & \multicolumn{3}{|c|}{06 May } & \multicolumn{3}{|c|}{08 May } & \multicolumn{3}{|c|}{10 May } & \multicolumn{3}{|c|}{13 May } \\
\hline & $m$ & $\mu$ & $r^{2}$ & $m$ & $\mu$ & $r^{2}$ & $m$ & $\mu$ & $r^{2}$ & $m$ & $\mu$ & $r^{2}$ & $m$ & $\mu$ & $r^{2}$ \\
\hline$\overline{\mathrm{AC}}$ & 0.39 & 0.66 & $0.84^{\mathrm{a}}$ & 0.51 & 0.60 & $0.73^{\mathrm{a}}$ & 0.23 & 0.36 & $\mathrm{a}$ & 0.39 & 0.91 & $0.76^{\mathrm{a}}$ & 0.58 & 0.16 & 0.91 \\
\hline Diatoms & & ns & & & ns & & & ns & & & $\mathrm{ns}$ & & 0.54 & 0.64 & $0.90^{\mathrm{a}}$ \\
\hline Synechococcus & 0.43 & 0.70 & $0.99^{\mathrm{a}}$ & 0.21 & 1.26 & $0.93^{\mathrm{a}}$ & 0.35 & 0.30 & 0.84 & 1.02 & 1.10 & 0.90 & 1.33 & 1.33 & $0.95^{\mathrm{a}}$ \\
\hline APF & 0.36 & 0.49 & 0.93 & & ns & & 1.02 & 1.04 & 0.71 & 0.87 & 1.67 & 0.70 & & $\mathrm{~ns}$ & \\
\hline Phaeocystis sp. & 0.43 & 0.70 & $0.86^{\mathrm{a}}$ & 0.57 & 0.61 & $0.74^{\mathrm{a}}$ & 0.26 & 0.38 & $\mathrm{a}$ & 0.43 & 0.96 & $0.76^{\mathrm{a}}$ & 0.62 & 0.15 & 0.89 \\
\hline $\mathrm{HC}$ & 0.69 & 1.24 & U & 0.97 & 1.03 & 0. & 1.36 & 1.37 & 0. & 1.25 & 1.48 & $0.87^{\mathrm{a}}$ & 1.48 & 1.31 & 0.95 \\
\hline HPF & 0.78 & 1.48 & $0.84^{\mathrm{a}}$ & 0.80 & 1.49 & $0.80^{\mathrm{a}}$ & 1.42 & 1.09 & 0.85 & 2.42 & 2.45 & $0.88^{\mathrm{a}}$ & 2.64 & 2.74 & 0.91 \\
\hline HNF & 0.00 & 1.09 & $0.95^{\mathrm{a}}$ & 1.20 & 1.00 & 0.93 & 1.15 & 1.59 & 0.91 & 1.60 & 1.70 & 0.72 & 2.36 & 3.08 & 0.85 \\
\hline HB & 1.73 & 1.42 & 0.93 & 1.45 & 1.78 & $0.86^{\mathrm{a}}$ & 1.15 & 1.20 & 0.81 & 1.52 & 1.86 & $0.96^{\mathrm{a}}$ & 1.20 & 1.23 & $0.91^{\mathrm{a}}$ \\
\hline $\mathrm{TC}$ & 0.44 & 0.77 & $0.96^{\mathrm{a}}$ & 0.52 & 0.53 & 0.67 & 0.48 & 0.53 & $\mathrm{a}$ & 0.51 & 1.00 & $0.75^{\mathrm{a}}$ & 0.65 & 0.25 & 0.90 \\
\hline
\end{tabular}


Click here to download Figure(s): Fig.1.doc

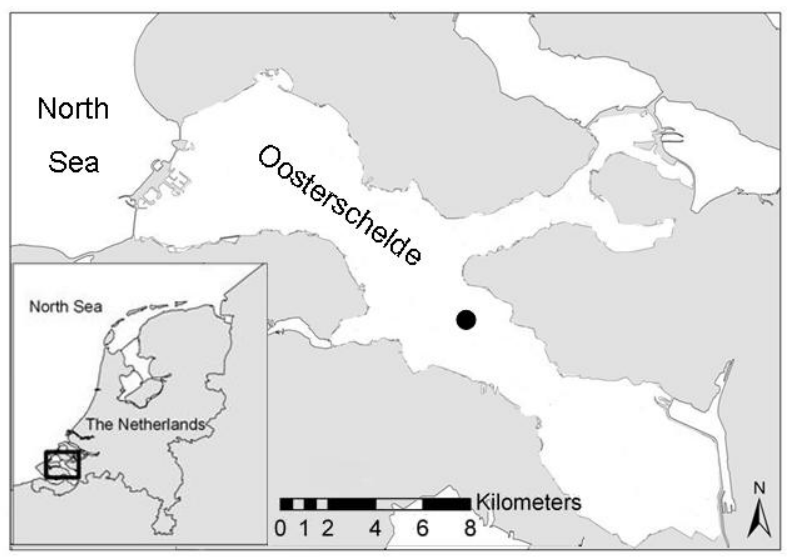

Fig. 1

Teixeira et al. 

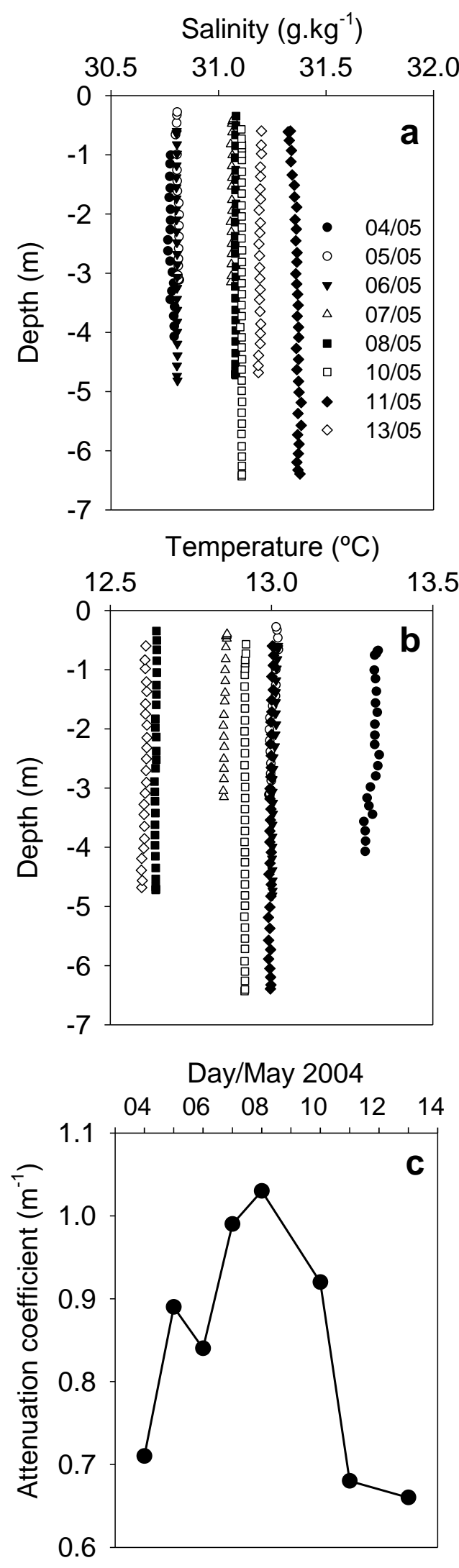

Fig. 2

Teixeira et al. 

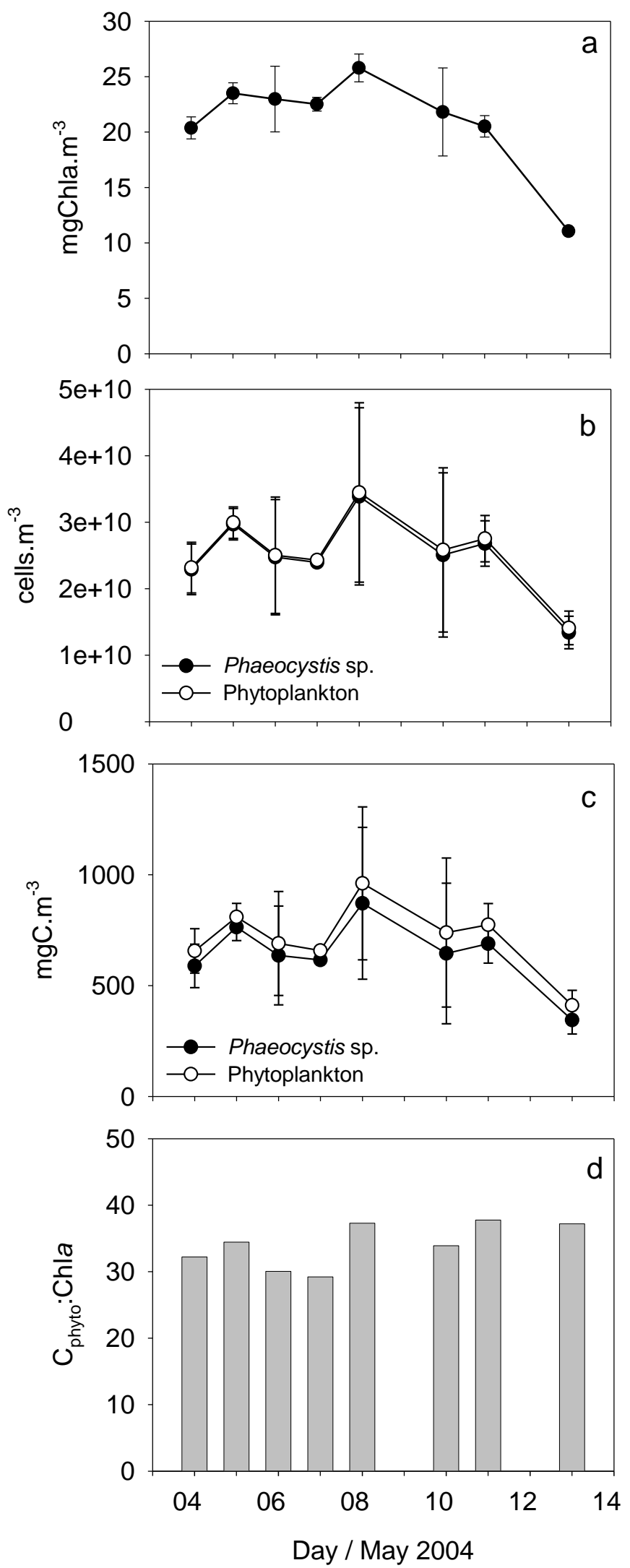

Fig. 3

Teixeira et al. 


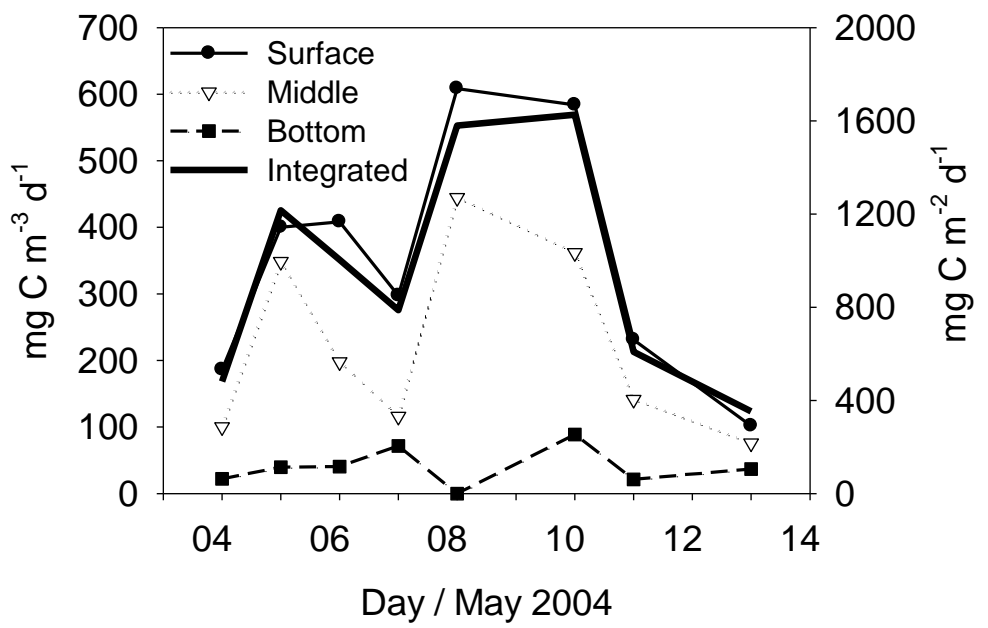

Fig. 4

Teixeira et al. 


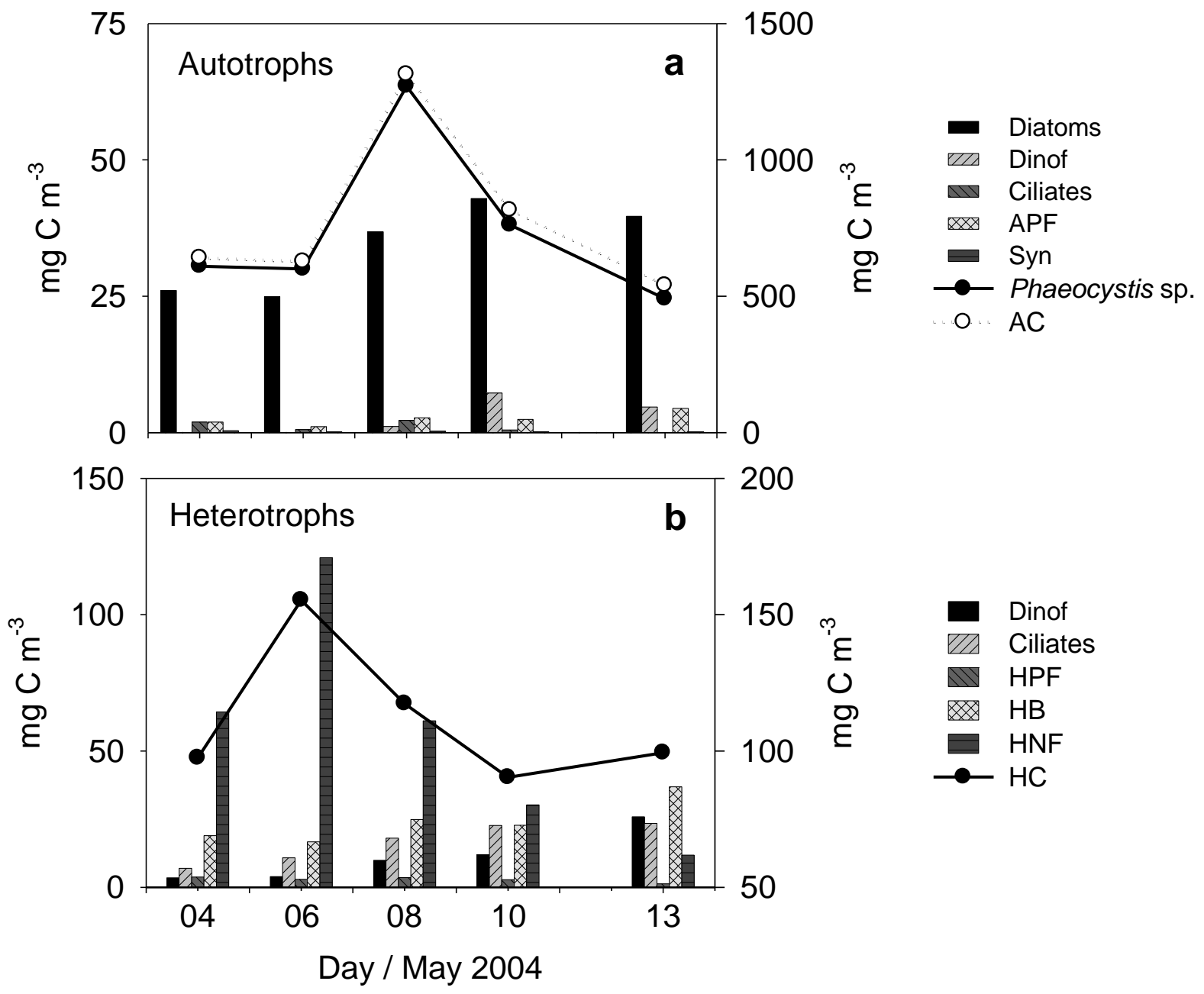

Fig. 5

Teixeira et al. 

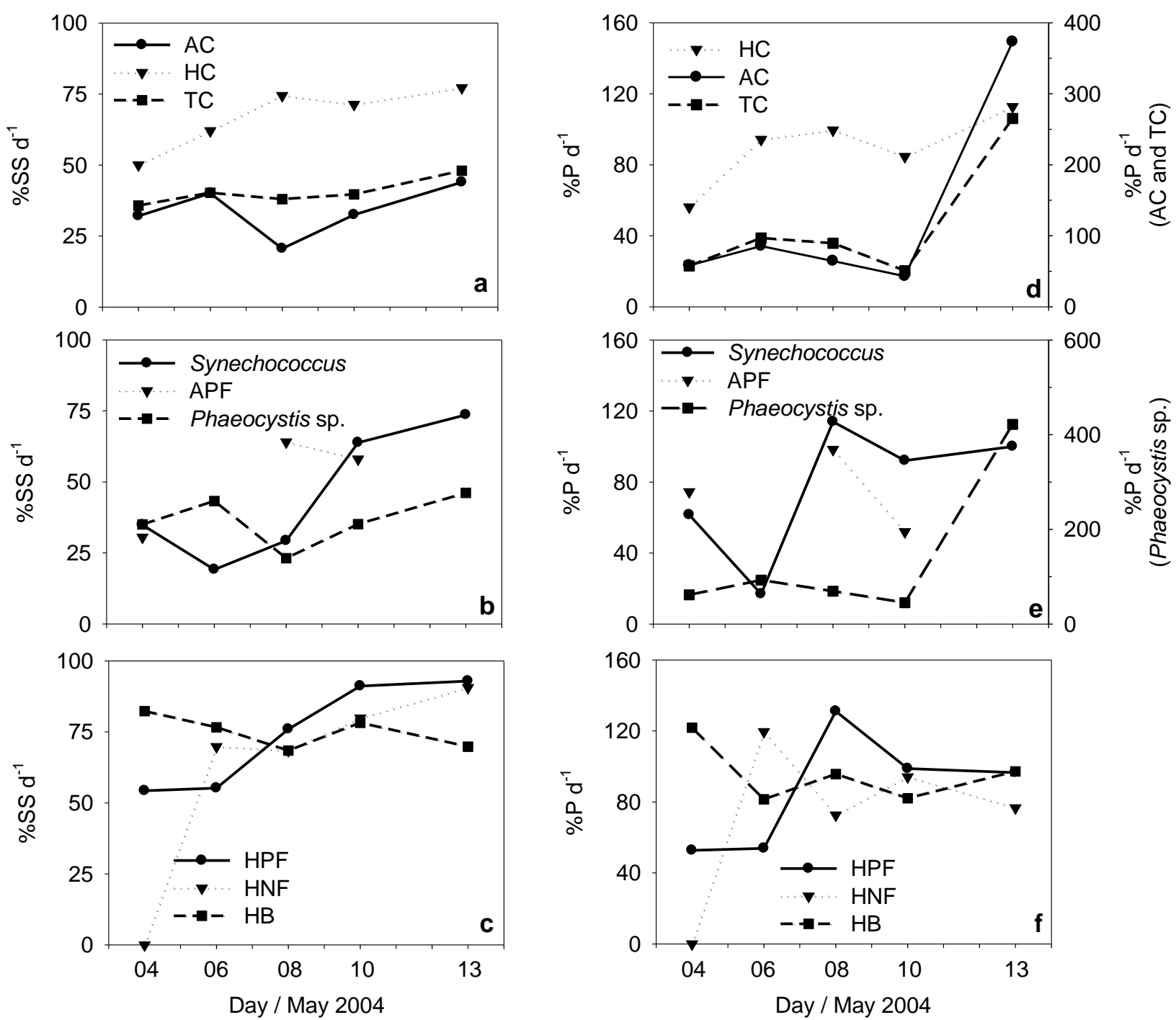

Fig. 6

Teixeira et al. 

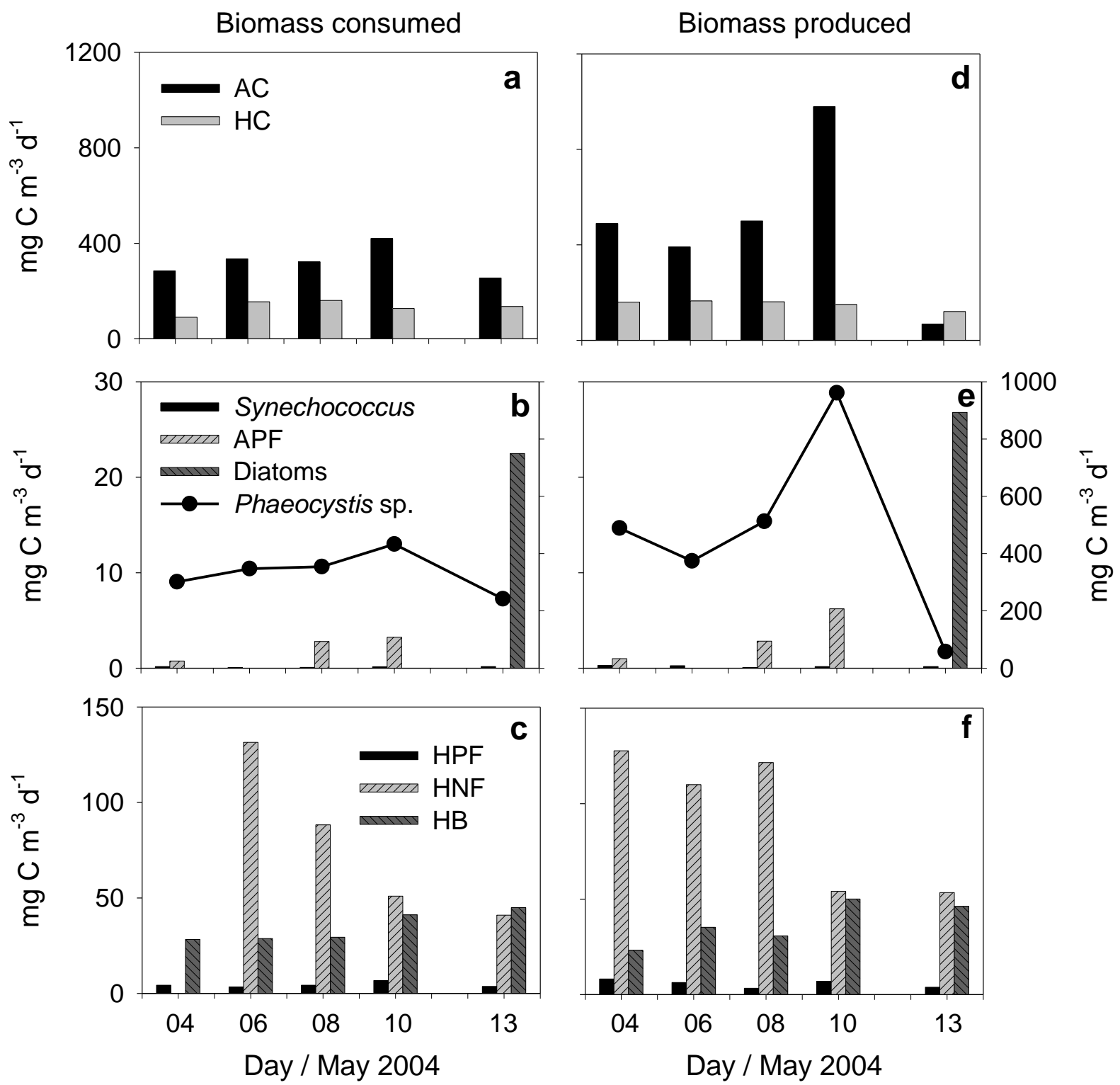

Fig.7

Teixeira et al. 
Figure 8

Click here to download Figure(s): Fig8.doc

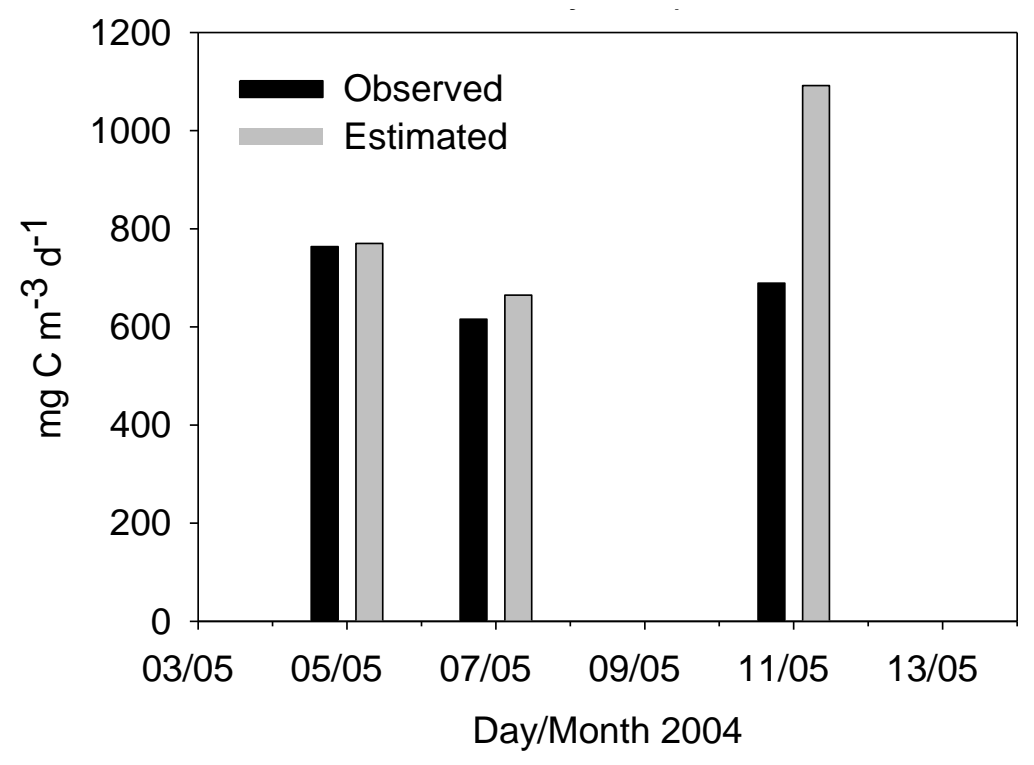

Fig. 8

Teixeira et al. 
Microzooplankton consumed a significant fraction of Phaeocystis sp. biomass.

Microzooplankton impact was higher during the bloom collapse, when cells were free-living. Heterotrophs were also consumed by microzooplankton simultaneously.

We observed two main pathways for channelling Phaeocystis sp bloom biomass. 